\title{
Toimiva pihatto työntekijän näkökulmasta
}

\author{
Veli-Matti Tuure ${ }^{1)}$, Janne Karttunen ${ }^{1)}$, Tapani Kivinen ${ }^{2)}$, Kim O. Kaustel1 ${ }^{3)}$, Kristiina Hakkarainen ${ }^{4)}$ ja \\ Timo Hurme ${ }^{5)}$ \\ ${ }^{1)}$ TTS tutkimus, Luonnonvara-ala, PL 5,05201 Rajamäki,veli-matti.tuure@tts.fi, \\ janne.karttunen@tts.fi \\ ${ }^{2}$ MTT Kotieläintuotannon tutkimus, Vakolantie 55,03400 Vihti, tapani.kivinen@mtt.fi \\ ${ }^{3)}$ MTT Taloustutkimus, Vakolantie 55, 03400 Vihti, kim.kaustell@mtt.fi \\ ${ }^{4)}$ Helsingin yliopisto, eläinlääketieteellinen tiedekunta, Kliinisen tuotantoeläinlääketieteen laitos, \\ Saaren yksikkö, Pohjoinen pikatie 800,04920 Saarentaus, kristiina.hakkarainen@helsinki.fi \\ ${ }^{5)}$ MTT Palveluyksikkö, 31400 Jokioinen, timo.hurme@mtt.fi
}

\section{Tiivistelmä}

Työntekijän kannalta toimivassa karjatalousrakennuksessa työt sujuvat, työn tuottavuus on hyvä, työn tekeminen ei vaaranna työntekijän terveyttä eikä turvallisuutta, työ on miellyttävää, sopivasti kuormittavaa ja se koetaan tarkoituksenmukaiseksi. Laajassa 100 nykyaikaisen suomalaisen pihaton tutkimuksessa pihaton toimivuutta työntekijän kannalta tutkittiin selvittämällä päivittäisten hoitotöiden työmäärään ja työntekijän tyytyväisyyteen vaikuttavat tekijät. Tutkimukseen otettiin mukaan vuosien 1990 ja 2002 välisenä aikana valmistuneita yli 40-paikkaisia lämpimiä makuuparsipihattoja, jolloin kohderyhmä edusti kotimaisen pihattosuunnittelun viimeaikaisimpia näkemyksiä ja ratkaisuja. Aineisto koottiin keväällä 2005 kyselyn ja tiloille tehtyjen tutkimuskäyntien avulla. Karjan tuotos- ja terveystarkkailutiedot saatiin Maatalouden Laskentakeskuksesta.

Työmäärävaihtelut samankokoisillakin nykyaikaisilla lypsykarjapihattotiloilla ovat hyvin suuria. Tässä aineistossa vaihtelua selittävät käytettävissä olevat työmenetelmät lypsyssä ja väkirehuruokinnassa, makuuparsien ja eläinten käytettävissä olevan tilan mitoitus, eläinten siirtoreitin suoruus eläintilasta lypsyasemalle sekä makuuparsien puhdistuskerrat ja lypsylle osallistuvien henkilöiden lukumäärä. Työmäärä riippuu siis koko työjärjestelmän toimivuudesta. Tutkimusaineistossa lypsyrobottitiloilla eläinkohtainen päivittäisten töiden työnmenekki oli runsaat 40 prosenttia pienempi kuin perinteisiä lypsyasematyyppejä käyttävillä tiloilla. Myös robottitilojen välillä oli hyvin suurta vaihtelua työnmenekissä. Erityisesti tulee välttää kaksinkertaisen lypsyjärjestelmän käyttöä. Tässä aineistossa eläintilassa oleviin rehukioskeihin perustuva väkirehun jakotapa on työtä säästävin väkirehumenetelmä; seosrehumenetelmä ei siis välttämättä tuo ajansäästöä ruokintaan. Makuuparsien tulee olla riittävän pitkiä (noin $250 \mathrm{~cm}$ ), jolloin puhtaanapitotöiden tarve pysyy kohtuullisena. Toimivassa lypsyssä lehmien tuloreitti lypsyasemalle on suora (korkeintaan yksi 90 -asteen käännös, mutta ei juuri ennen asemalle tuloa) ja lypsyasemalla työskentelee vain yksi henkilö ainakin 55-70 lypsylehmän karjakokoon asti. Merkittävällä osalla suomalaisista ja myös tässä tutkimuksessa mukana olevista maitotiloista karjanhoitotöiden tehokasta organisointia vaikeuttaa perinteinen pyrkimys työllistää kaksi tai jopa useampia työntekijöitä karjamäärästä riippumatta.

Eniten tyytymättömyyttä aiheuttivat tutkimustiloilla lehmien ajon tarve lypsylle ja siitä johtuva lypsyn venyminen sekä niska-hartiavaivat, jotka yleistyvät karjamäärän kasvaessa. Työn yksipuolistuminen ja painottuminen nopeatahtiseen ja kestoltaan pidentyvään lypsyyn uhkaa laajentavan lypsykarjatilan työntekijöiden terveyttä. Toimiviksi koettuja ratkaisuja olivat puolestaan eläintilassa oleviin kioskeihin perustuva väkirehuruokinta sekä seosrehuruokinnassa kurottajan käyttö rehukomponenttien lastauksessa.

\section{Asiasanat}

Työmäärä, pihatto, maidontuotanto, työtyytyväisyys, suunnittelu, organisointi 


\section{Johdanto}

Karjatalousrakennus on eläinten hoitajan työpaikka - vieläpä vuoden jokaisena päivänä. Tässä artikkelissa tarkastellaan lypsykarjapihaton toimivuutta työntekijän näkökulmasta. Tarkastelun tavoitteena on tuoda esille ne ratkaisut, jotka lämpimässä makuuparsipihatossa johtavat pieniin eläinkohtaisiin työnmenekkeihin ja toisaalta työntekijöiden (eläinten hoitajien) tyytyväisyyteen.

\section{Työmäärä lypsykarjapihattotiloilla}

Karttusen (2004) tekemien päivittäisten karjanhoitotöiden keskimääräiseen kokonaistyönmenekkiin perustuvien laskelmien mukaan koneellistetussa lämminpihatossa, jossa on tavanomainen lypsyasema ja lypsyn sujuvuus, pitäisi kaikista 60 lypsylehmän ja vastaavan nuorkarjan vaatimista karjanhoitotöistä selvitä hieman alle kymmenessä minuutissa lypsylehmää ja vuorokautta kohti. Vastaavankokoisessa automaattilypsyllä varustetussa pihatossa kaikista karjanhoitotöistä tulisi selvitä keskimäärin noin seitsemässä minuutissa lehmää ja vuorokautta kohti. On huomattava, että näissä laskelmissa on mukana myös ns. muut navettatyöt, kuten eläinten siirrot, tarkastuskäynnit, poikimisten tarkkailut yms., joiden osuus oli laskelmissa noin viidennes karjanhoitotöiden päivittäisestä kokonaistyönmenekistä.

Karttusen ja Peltosen (2004) työntutkimuksissa todettiin tavanomaisilla lypsyasemilla varustetuissa pihattonavetoissa $(n=20)$ 40-50 lypsylehmän hoidon työnmenekissä vuositasolla suurimmillaan noin 2700 henkilötyötunnin eroja. Esimerkiksi noin 50 lypsylehmän pihattotiloilla karjanhoitotöihin kului keskimäärin noin kymmenen minuuttia lehmää ja vuorokautta kohti vaihtelun ollessa noin kuudesta minuutista noin 15 minuuttiin lehmää ja vuorokautta kohti. Tässä työnmenekissä eivät ole mukana tarkastuskäynnit eivätkä muut "normaalin" navettatyöajan ulkopuoliset karjanhoidon työtehtävät kuten poikimisten avustaminen. Latvalan ja Suokannaksen (2005) kyselytutkimuksessa lypsyn automatisoineilla pihattotiloilla $(n=22)$ karjanhoitotöihin kului keskimäärin 12 henkilötyöminuuttia lehmää ja vuorokautta kohti. Tilojen välinen työnmenekin vaihtelu oli kuitenkin hyvin suurta. Karttusen ja Hämäläisen (2003) työnmenekkilaskelmien mukaan lypsyrobotin hankkivat tilat voivat käytännössä odottaa lypsyn automatisoinnin ansiosta päivittäistä runsaan kahden tunnin - viiden tunnin työnsäästöä 50 lypsylehmän karjassa verrattuna tavanomaisesti sujuvaan asemalypsyyn. Lypsyn automatisoinnilla saavutettava työnsäästö riippuu töiden organisoinnista ja karjanhoidossa käytettävistä koneista ja laitteista, eläinmäärästä ja eläinaineksen laadusta ennen ja jälkeen muutoksen. Karttusen ja Hämäläisen (2003) mukaan karjaa on tarvittaessa varauduttava määrätietoisesti karsimaan, jotta työnsäästöpotentiaali ei hupene muutamien yksittäisten lehmien hoitoon. Työnkäytöllisesti ei voida missään tapauksessa suositella sitä, että osa lehmistä lypsetään edelleen kahdesti päivässä vanhassa lypsyasemassa. Tästä syystä automaattilypsytiloilla tuotannon laajentamista suunnitellaan yleensä noin 60-70 lehmän kerranteina. Kun lypsyn automatisointi saadaan toimimaan, kannattaa säästyvä työaika jakaa tarkkaan harkiten oman vapaa-ajan lisäämisen, eläinten hyvinvoinnin - esimerkiksi puhtaanapidon - edistämisen ja eläinmäärän kasvattamisen kesken.

\section{Työntekijän hyvinvointi}

Työntekijän hyvinvointi muodostuu usean tekijän vaikutuksesta, ja se voi toteutua pitkällä aikavälillä vain samanaikaisesti toteutuvan toiminnan tehokkuuden kanssa; onhan tehokkuuden vastakohtana tehottomuus, joka on resurssien - myös ihmistyön - epätarkoituksenmukaista käyttöä. Hyvinvoinnin ja tehokkuuden saavuttaminen puolestaan edellyttävät, että työolosuhteet ja -välineet ovat asianmukaiset, työn sisältö on tarkoituksenmukainen, työtaidot vastaavat työn vaatimuksia ja että tuotannonohjausjärjestelmä - työn suunnittelu ja muu käytännön johtamistyö - on kunnossa.

Suomalaisilla maitotiloilla - ja niistä erityisesti karjamäärältään suurilla - työssä jaksamista haittaa viljelijäkyselyn mukaan eniten vuotuinen työn määrä (Suomen Gallup Elintarviketieto 2006, haastateltu 4100 aktiivitilaa, joista 1300 maitotiloja). Maamme työväestöön, maatalousyrittäjät mukaan lukien, kohdistuneissa tutkimuksissa on todettu, että työuupumus yleistyy niillä työntekijöillä, jotka tekevät jatkuvasti 55 tuntia tai enemmän töitä viikossa (Kalimo ja Toppinen 1997). Erityisesti maidontuottajat tekevät kannattavuuskirjanpitotilojen työaikakirjanpidon mukaan maataloustöitä usein tätä enemmän (MTT 2006). Jo yli kahdeksan tunnin yhtämittainen työpäivä alkaa kasvattaa tapaturmariskiä ja yli 12 tunnin työpäivä kaksinkertaistaa sen (Dong 2005). Univajeen riskin on todettu kaksinkertaistuvan, jos viikkotyöaika ylittää 50 tuntia. Univajeesta seuraa fyysisiä ja psyykkisiä ongelmia, jotka ilmenevät muun muassa lisääntyneenä onnettomuus- ja tapaturmariskinä sekä sairastumisriskinä. 
Tämä johtuu mm. riskinottokynnyksen madaltumisesta ja ei-turvallisten työskentelytapojen yleistymisestä väsymyksen seurauksena (Härmä ja Sallinen 2004, 2000, Kecklund 2005). Pitkä työpäivä rajoittaa myös palautumismahdollisuuksia työkuormituksen rasituksesta.

Ruotsalaiset viljelijät arvioivat itse suurien maitotilojen fyysisesti kuormittavimmiksi töiksi konelypsyn ja rehunkäsittelyn (Kolstrup ym. 2006). Myös lannanpoistotöiden kuormitukseen tulee kiinnittää huomiota. Yli 50 lypsylehmän pihattotiloille ja ulkopuolisia henkilöitä lypsytyöhön palkkaaville tiloille tehdyn kyselyn (Kolstrup ym. 2007) mukaan suurimpia työympäristön haittatekijöitä ovat toistotyö (36 \% vastaajista; $n=102)$, huonot lämpöolot (27\%) ja pölyt (23\%).

\section{Aineisto ja menetelmät}

Tutkimusaineisto kerättiin sadalta suomalaiselta karjantarkkailussa mukana olevalta lypsykarjapihattotilalta, joilla oli 1990-2002 välisenä aikana rakennettu lämmin parsipihattonavetta. Keväällä 2005 kerätty tutkimusaineisto koostui tiloilta saadusta kyselyaineistosta, sitä täydentävästä tilakäyntiaineistosta ja karjan tuotos- ja terveystarkkailutiedoista. Tilakäynneillä tietoa kerättiin havainnoimalla, haastattelemalla ja mittaamalla. Tiloilla tapahtuneen tiedonkeruun suoritti viisi Valio Oy:n neuvonta-agrologia ja johtava eläinlääkäri sekä tutkijat. Karjan tuotos- ja terveystarkkailutiedot saatiin Maatalouden Laskentakeskuksesta.

Tutkimusaineisto tallennettiin taulukkolaskentaohjelman tallennuspohjalle kolmessa tutkimukseen osallistuvassa tutkimusyksikössä: HY:n eläinlääketieteellisessä tiedekunnassa, TTS:n maatalousosastolla ja MTT maatalousteknologian tutkimusyksikössä. Tiedonkeruulomakkeilta tallennettiin tietoja yhteensä 10001 muuttujasta jokaista tilaa kohden. Tässä muuttujamäärässä eivät vielä ole mukana karjantarkkailutiedot.

Tutkimusaineistosta koostettiin alkuvaiheessa kuvailevia analyysejä, ja joitakin jatkuvia muuttujia luokiteltiin. Rakennusten pohjapiirustuksista määritettiin $\mathrm{mm}$. pinta-aloja, jotka lisättiin aineistoon. Pihaton toimivuutta ihmisen kannalta tutkittiin työnmenekin ja työntekijän tyytyväisyyden avulla. Näiden vastemuuttujien selvityksessä aineisto koostui lopulta 91 lypsykarjatilan tiedoista, sillä 100 pihaton perusaineiston yhdeksällä tilalla oli huomattava määrä lihakarjaa, jonka mahdollinen vaikutus tuloksiin haluttiin poistaa. Yhteensä 12 tilalle tehtiin lisäksi erillinen työntutkimuskäynti. Nämä 12 tilaa valittiin tilan ilmoittaman eläinkohtaisen työnmenekin perusteella; mukaan otettiin sekä suuritöisiä että pienitöisiä pihattoja.

Lehmää kohti laskettuun päivittäiseen työnmenekkiin vaikuttavia tekijöitä tarkasteltiin usean selittävän muuttujan lineaarisen mallin avulla ja tyytyväisyyteen vaikuttavia tekijöitä usean selittävän muuttujan logistisen mallin avulla. Logistista mallia käytettiin, koska tyytyväisyyttä tarkasteltiin kaksiluokkaisena muuttujana, jolle normaalijakaumaoletus ei ole realistinen. Koska mahdollisia vastemuuttujan vaihtelua selittäviä tekijöitä oli hyvin suuri määrä, mallinnus toteutettiin useassa vaiheessa. Ensin testattiin vastemuuttujaan mahdollisesti vaikuttavat yleisluonteiset sekoittavat tekijät, sitten huomioitavat ja erityisesti kuhunkin vastemuuttujaan liittyvät sekoittavat tekijät ja lopuksi kuhunkin vastemuuttujaan liittyvät muut varsinaiset selittävät tekijät ja vielä kaikille vastemuuttujille yhteiset rakennusmuuttujat. Lopulta saatiin mallit, joissa kaikki selittäjät olivat tilastollisesti merkitseviä. Tilastolliset analyysit toteutettiin SAS-ohjelmistolla MIXED-proseduurilla.

Työntutkimuskäyntien 12 kohdetilalla mitattiin päivittäisten navettatöiden työajat, kartoitettiin kaikkien navettatöiden suoritustavat ja organisointi, töissä käytetyt koneet ja navetan sekä rehuvarastojen sisätilat. Tilakäynnit suoritettiin kaikilla 12 tilalla kahden henkilön, tutkijan ja työntutkijan, toimesta.

\section{Tulokset ja tulosten tarkastelu}

\section{Päivittäisten töiden työnmenekki}

Monimuuttujamallin mukaan työnmenekkiä (työmäärä/lehmä/päivä) selittävät sekä työmenetelmät, töiden organisointiin liittyvät tekijät että pihaton mitoitukseen liittyvät tekijät (taulukko 1). Malliin jääneiden kahdeksan muuttujan avulla voidaan selittää tutkimustilojen päivittäisen työnmenekin vaihtelusta noin $71 \%$. Mielenkiintoista näissä tuloksissa on se, että eläinmäärä ei jäänyt malliin selittäväksi tekijäksi; eläinmäärä vaikuttaa vasta välillisesti työmenetelmien ja töiden organisoinnin kautta. 
Taulukko 1. Työmäärää (min/lehmä/päivä)* vaikuttavat tekijät keskiarvoestimaatteineen ja merkitsevyystasoineen.

\begin{tabular}{|c|c|c|c|c|c|}
\hline muuttuja & arvo & keskiarvoestimaatti* & alaraja & yläraja & P-arvo \\
\hline \multirow[t]{3}{*}{ Lypsyasemamalli } & tandem & 17,2614 & 14,5461 & 19,9767 & 0,0052 \\
\hline & kalanruoto & 15,8175 & 13,5186 & 18,1164 & \\
\hline & robotti & 9,4087 & 5,2760 & 13,5414 & \\
\hline \multirow{3}{*}{$\begin{array}{l}\text { Parren pituus, } \mathrm{cm} \text {, päät } \\
\text { vastakkain olevat } \\
\text { parret }\end{array}$} & $<230$ & 16,9964 & 14,5444 & 19,4483 & 0,0126 \\
\hline & $230-250$ & 14,3996 & 12,3745 & 16,4247 & \\
\hline & $>250$ & 11,0916 & 6,4145 & 15,7687 & \\
\hline \multirow{3}{*}{$\begin{array}{l}\text { Parren pituus, cm, } \\
\text { parret seinää vasten }\end{array}$} & $<230$ & 16,2004 & 13,3215 & 19,0794 & 0,0911 \\
\hline & $230-250$ & 12,7776 & 10,6881 & 14,8672 & \\
\hline & $>250$ & 13,5095 & 9,9886 & 17,0304 & \\
\hline \multirow[t]{3}{*}{ Väkirehumenetelmä } & kioskit & 11,6722 & 9,4933 & 13,8511 & 0,0027 \\
\hline & seosrehu & 13,5741 & 10,9493 & 16,1989 & \\
\hline & muu väkirehu & 17,2413 & 14,0735 & 20,4090 & \\
\hline \multirow{3}{*}{$\begin{array}{l}\text { Lypsylle osallistuvien } \\
\text { henkilöiden lukumäärä }\end{array}$} & 1 & 11,8312 & 9,7363 & 13,9261 & 0,0024 \\
\hline & 1,5 & 14,3284 & 11,5152 & 17,1417 & \\
\hline & 2 & 16,3280 & 13,5842 & 19,0718 & \\
\hline \multirow{2}{*}{$\begin{array}{l}\text { Lehmäliikenteessä } \\
\text { sujuvuusongelmia }\end{array}$} & kyllä & 15,4683 & 13,1230 & 17,8137 & 0,0137 \\
\hline & ei & 12,8568 & 10,5297 & 15,1838 & \\
\hline $\begin{array}{l}\text { Lehmien käytössä oleva } \\
\text { pinta-ala, } m^{2} \text { per } \\
\text { parsipaikka }\end{array}$ & & & & & 0,0027 \\
\hline $\begin{array}{l}\text { Makuuparsien } \\
\text { lannanpoisto- ja } \\
\text { puhdistuskerrat }\end{array}$ & & & & & $<0,0053$ \\
\hline
\end{tabular}

Merkittävimmin päivittäinen työmäärä (työmäärä/lehmä/päivä) riippuu lypsyasemamallista $(\mathrm{p}<0,01)$, päittäin vastakkain olevien makuuparsien pituudesta $(\mathrm{p}<0,1)$ ja väkirehumenetelmästä (varastosta ruokintapöydälle; $p<0,01)$. Seuraavaksi eniten työmäärään vaikuttavat lypsylle osallistuvien henkilöiden määrä $(p<0,01)$, seinää vasten olevien parsien pituus $(p<0,1)$ lehmäliikenteen sujuminen $(p<0,1)$, lehmää kohti käytössä oleva pihaton pinta-ala $(\mathrm{p}<0,01)$ ja makuuparsien lannanpoisto- ja puhdistuskertojen lukumäärä päivässä $(\mathrm{p}<0,01)$. Kaksi viimeksi mainittua muuttujaa vaikuttavat kertoimien kautta; lypsylehmää kohti käytössä oleva lisäneliö kasvattaa työmäärää saman verran kuin makuuparsien "ylimääräinen" lannanpoisto- ja puhdistuskerta.

Automaattilypsyyn siirtyneiden tilojen eläinkohtainen karjanhoitotöiden keskimääräinen työnmenekki oli selvästi (noin $40 \%$ ) pienempi kuin muita lypsyjärjestelmiä käyttävien tilojen vastaava työnmenekki. Toimiva, tehokas, järjestelmä edellyttää kuitenkin sitä, että lypsyrobotin rinnalla ei ole toista järjestelmää robottiin soveltumattomien lehmien lypsämiseen. Tässä aineistossa lypsyrobottitiloilla työnmenekki oli keskimäärin $6-8 \mathrm{~min} / \mathrm{lehmä/pv}$ pienempi kuin perinteisten lypsyasemien tiloilla.

Lyhyt parsi oli työmäärän kannalta huonoin vaihtoehto. Tiedetään, että liian lyhyet parret lisäävät lehmien seisomista etujalat parressa ja takajalat lantakäytävällä (Galindo ja Broom 2000). On mahdollista, että lyhyen parren vaikutus työmäärään selittyy lisääntyneellä lehmien puhdistustarpeella. Tiloilla, joilla parren pituus oli vähintään $2500 \mathrm{~mm}$, työnmenekki oli pienin. 
Tässä aineistossa eläintilassa oleviin rehukioskeihin perustuva väkirehun jakotapa on työtä säästävin väkirehumenetelmä; seosrehumenetelmä ei siis välttämättä tuo ajansäästöä ruokintaan. Tiloilla parhaimmiksi seosrehumenetelmiksi arvioitiin järjestelmät, joissa väkirehu varastoitiin siiloihin ja kiskoruokkija hoiti rehun sekoituksen ja jakamisen.

Pihaton työnjako on toimivin, kun lypsyasemalla työskentelee vain yksi henkilö ainakin 55-70 lypsylehmän karjakokoon asti. Työntekijöiden lukumäärän työnmenekkiä lisäävä vaikutus tutkimustiloilla johtunee pääasiassa siitä, että lypsy ei täysin työllistä kahta henkilöä, jolloin työ jää tehottomaksi. Lypsy päivittäisenä eniten aikaa vaativana työnä puolestaan on avainasemassa kokonaistyömäärää tarkasteltaessa.

Eläimen lypsylle ajon tarve kuvaa lehmäliikenteen sujuvuutta. Lehmäliikenteen sujuvuusongelmat lisääntyvät, jos lehmän lypsyreitillä (eläintilasta lypsyasemalle) on kaksi tai useampi 90 asteen mutka. Toimivassa pihatossa lehmien tuloreitti lypsyasemalle on siis suora (korkeintaan yksi 90-asteen käännös eikä sekään juuri ennen asemalle tuloa). Myös poistumisreitti lypsyasemalta kannattaa tehdä mahdollisimman suoraksi ja lyhyeksi.

Työntutkimuskäynnit 12 pihattotilalle tukivat monimuuttuja-analyysin tuloksia: lypsy ja siten myös kaikki karjanhoitotyöt tehtiin tehokkaimmin tiloilla, joilla oli täysimittainen kokoomatila, lypsystä vastasi yksi työntekijä (60-80 lypsylehmän karjoissa) toisen tehdessä muut karjanhoitotyöt, lypsyrutiinit olivat (lähes) uusimpien suositusten mukaiset ja mahdollisten rakopalkkilattioiden puhdistuksen hoiti lantaraappa. Pyöröpaaleihin perustuvan säilörehun käsittely on yleensä ja erityisesti seosrehuruokinnassa työläämpää kuin laakasiiloon säilötyn säilörehun käsittely.

\section{Työntekijöiden tyytyväisyys}

Työntekijöiden tyytyväisyyttä pihaton toimivuuteen, työoloihin ja työmäärään selittivät tilastollisen tarkastelun perusteella vain kaksi muuttujaa (taulukko 2): niska-hartiavaivojen esiintyminen ja lypsytyön kokonaiskesto (min/lypsykerta). Usein särystä kärsivien tyytymättömyyden riski on noin 19,6kertainen verrattuna niihin, joilla ei esiinny särkyä. Lypsytyön kokonaiskestoajan lisääntyessä minuutilla per kerta, tyytymättömyyden riski kasvaa keskimäärin 1,026-kertaiseksi eli noin 2,6 prosenttia.

Taulukko 2. Työntekijöiden tyytyväisyyttä selittävät muuttujat, niiden estimaatit ja luottamusvälien rajat.

\begin{tabular}{|l|r|r|r|}
\hline \multicolumn{4}{|c|}{ Odds Ratio Estimates } \\
\hline Effect & \multicolumn{1}{l|}{$\begin{array}{l}\text { Point } \\
\text { Estimate }\end{array}$} & $\begin{array}{l}\text { 95\% Wald } \\
\text { Confidence }\end{array}$ & \multicolumn{2}{l|}{ Limits } \\
\hline Niska-hartiavaivat: harvoin vs. ei esiinny & 0,862 & 0,178 & 4,177 \\
\hline Niska-hartiavaivat: usein vs. ei esiinny & 0,051 & 0,007 & 0,373 \\
\hline Niska-hartiavaivat: jatkuvasti vs. ei esiinny & 0,118 & 0,012 & 1,151 \\
\hline Lypsytyön kokonaiskesto & 0,975 & 0,956 & 0,995 \\
\hline Vesiastiatyyppi: sekä altaat että kupit vs kupit & 3,923 & 0,875 & 17,584 \\
\hline
\end{tabular}

Vastaajista lähes kolmannes (30,8 \%) ilmoitti niska-hartiavaivoja esiintyvän usein tai lähes jatkuvasti. Vain $16 \%$ ei kärsinyt kyseisistä vaivoista koskaan. Päivittäisiin lypsykarjanhoitotöihin ilmoitettiin kuluvan työaikaa sisäruokintakaudella keskimäärin 12,7 tuntia. Tiloilla oli vakinaista työvoimaa keskimäärin 2,1 henkilöä, jolloin työmääräksi kertyy keskimäärin $6 \mathrm{~h} /$ päivä/vakinainen työntekijä. Tutkimusaineistossa niska-hartiavaivojen esiintyminen yleistyi, kun lypsylehmien lukumäärä (keskilehmäluku) kasvoi ja ryhmittely yleistyi, käsikolaa käytettiin makuuparsien kuivituksessa ja kannettavaa astiaa väkirehun siirrossa ja kun käsien kylmähaitat yleistyivät.

Eläinmäärän kasvaessa työ keskittyy entistä selvemmin lypsyasemalle muissa kuin lypsyrobottiratkaisuissa. Työntekijän kannalta keskeisiksi epäkohdiksi muodostuvat tällöin lypsytyöajan pidentyminen, työn muuttuminen yksipuolisemmaksi ja nopeatahtisemmaksi sekä näistä aiheutuvat niska- 
hartiavaivat. Haittojen minimoimiseksi sekä lypsyn kestoa että kuormitustasoa olisi saatava pienemmäksi.

\section{Johtopäätökset}

Päivittäisen työmäärän hallinta lypsykarjapihattotilalla edellyttää monimuuttujamallin mukaan koko työjärjestelmän hallintaa - työmäärä riippuu siis koko työjärjestelmän toimivuudesta. Työmenetelmät, työn organisointi ja olosuhteet - pihaton tilaratkaisut ja mitoitukset mukaan lukien - selittävät noin 70 \% päivittäisten lehmää kohti laskettujen eläintenhoitotöiden työmäärästä. Osa selittämättä jääneestä vaihtelusta aiheutunee eroista työtavoissa, työtaidoissa, työmotivaatiossa ja -asenteissa. Ulkomaisiin vastaavanlaisiin pihattoihin verrattuna suomalaisilla maitotiloilla käytetään keskimäärin hyvin selvästi enemmän työaikaa lehmää kohden. Tätä eroa ei voida läheskään kaikissa tapauksissa perustella karjan hyvinvoinnin edistämisellä tai korkeamman ja laadullisesti paremman tuotostason tavoittelulla. Merkittävä ero työnmenekissä kertonee murrosvaiheesta, jossa vanhoista pienten pihatoiden tai parsinavetoiden työmenetelmistä ollaan siirtymässä uusiin. Tuotantoeläimet näyttävät sopeutuvan paljon ihmistä nopeammin karjanhoidon tekniikassa ja tuotantoympäristössä tapahtuviin muutoksiin.

Karjamäärän kasvattaminen perustuu suureksi osaksi tehokkaamman tekniikan käyttöönottoon. Automaatio tuo muutoksia niin työmäärään kuin työn laatuunkin. Tällöin korostuu lypsyn merkitys ihmistyötä eniten vaativana työnä. Tavanomaista lypsytekniikkaa käyttävillä tiloilla ongelmana on työn yksipuolistuminen, lypsyrupeaminen venyminen ja lypsyrytmin kiristyminen, mitkä tämänkin tutkimuksen aineiston mukaan lisäävät niska-hartiavaivojen yleisyyttä ja työtyytymättömyyttä. Tulokset tukevat täysin viimeaikaisia tutkimuksia suurten lypsykarjatilojen lypsytyön kuormituksesta (mm. Pinzke ym. 2001, Pinzke 2003, Stål ym. 2003, Kolstrup ym. 2006). Lypsäjän yläraajoihin ja hartioihin kohdistuvan kuormituksen hallitsemiseksi ja oireiden välttämiseksi on ehdotettu seuraavia toimenpiteitä:

- kuormitushuippuja ja käsien/ranteiden ääriasentoja sisältävien lypsyn päätyönvaiheiden (utareen pyyhkiminen, alkusuihkeiden otto, lypsinten kiinnitys) lyhentäminen altistumisajan lyhentämiseksi (Pinzke ym. 2001); mm. automaattisen pesukupin kehittäminen (Pinzke 2003),

- lypsinten keventäminen (Nevala-Puranen ym. 1996, Pinzke ym. 2001); keveimmät lypsimet ovat alle 1,5 kg:n painoisia (Jakob ja Rose 2007),

- lypsinten kannattimet (Pinzke 2003),

- $\quad$ säädettävä lypsysyvennyksen lattiataso (Pinzke 2003); sopiva syvyys on noin 50 \% lypsäjän pituudesta (Nevala-Puranen 1996),

- lyhyiden lepotaukojen pitäminen lypsyn aikana (Nevala-Puranen 1996); tämä on kuitenkin ongelmallista karusellilypsyasemilla (Stål ym. 2003),

- työkierron järjestäminen (Stål ym. 2003),

- $\quad$ oikeaoppisten työasentojen ja -tekniikoiden edistäminen (Kolstrup ym. 2006).

\section{Kiitokset}

Tutkimuksen rahoitti maa- ja metsätalousministeriön maatilatalouden kehittämisrahasto. Yritysrahoituksen osuus tuli työpanoksen muodossa Valio Oy:ltä. Parhaat kiitokset rahoittajille ja niille noin 30 henkilölle, jotka tutkimuksen eri vaiheissa osallistuivat siihen. Lämpimät kiitokset niille sadalle lypsykarjatilalle, joiden yhteistyö mahdollisti tutkimuksen toteuttamisen.

\section{Kirjallisuus}

Dong, X. 2005. Long workhours, work scheduling and work-related injuries among construction workers in the United States. Scand J Work Environ Health 31(5): 329-335.

Galindo, F. \& Broom, D. M. 2000. The relationships between social behaviour of dairy cows and the occurrence of lameness in three herds. Res Vet Sci 69:75-79.

Härmä, M. \& Sallinen, M. 2000. Univaje terveysriskinä. Duodecim 116: 2267-2273.

Härmä, M. \& Sallinen, M. 2004. Hyvä uni - Hyvä työ. Työterveyslaitos. Helsinki. 105 s.

Jakob, M. \& Rose, S. 2007. Einfluss der Melkstandausstattung auf die Arbeitsbelastung des Melkers. 15th seminar of work science, VDI-MEG-working group Work Science in Agriculture. Österreichisches Kuratorium für Landtechnik und Landentwicklung, Landtechnishe Schriftenreihe 230: 78-83. 
Kalimo, R. \& Toppinen, S. 1997. Työuupumus Suomen työikäisellä väestöllä. Työterveyslaitos. Helsinki. 63 s. Karttunen, J. 2004. Maidontuottajien teknologiavalinnat suurissa tuotantoyksiköissä - Karkearehun käsittelyketjut ja karjanhoitotöiden työnmenekki. Työtehoseuran julkaisuja $394.73 \mathrm{~s}$.

Karttunen, J. \& Hämäläinen, M. 2003. Automaattilypsyn työnmenekki ja toiminnallisuus - Työn luonteen muutos lypsyrobotin myötä. Työtehoseuran maataloustiedote (563) $12.8 \mathrm{~s}$.

Karttunen, J. \& Peltonen, M. 2004. Lypsyn ja puhtaanapitotöiden työnmenekki pihatossa. Teoksessa: UusiKämppä, J. \& Rissanen, P. (toim.). Suuret pihatot - eläinten hyvinvointi, lypsyn työnmenekki, työolot ja ympäristönhoito. Maa- ja elintarviketalouden tutkimuskeskus. Ympäristö. Maa- ja elintarviketalous 47. s. 58-70.

Kecklund, G. 2005. Long workhours are a safety risk - causes and practical legislative implications. Scandinavian Journal of Environmental Health, 31(5):325-327.

Kolstrup, C., Bratt, J. \& Eriksson, W. 2007. Musculoskeletal disorders among Swedish dairy farmers and workers. 15th seminar of work science, VDI-MEG-working group Work Science in Agriculture. Österreichisches Kuratorium für Landtechnik und Landentwicklung, Landtechnishe Schriftenreihe 230: 84-88.

Kolstrup, C., Stål, M., Pinzke \& Lundqvist, P. 2006. Ache, pain, and discomfort: the reward for working with many cows and sows? Journal of Agromedicine 11(2): 45-55.

Latvala, T. \& Suokannas, A. 2005. Automaattisen lypsyjärjestelmän käyttöönotto: kannattavuus ja hankintaan vaikuttavat tekijät. Pellervon taloudellisen tutkimuslaitoksen raportteja n:o 192. 85 s. ISBN 952-5299-90-2 (NID), ISBN 952-5299-91-0 (PDF), ISSN 1456-3215.

MTT. 2006. Kannattavuuskirjanpitotilojen tuloksia 1998-2005. Saatavilla: https://portal.mmt.fi/portal/page/ portal/taloustohtori/2003/Tunnusluvut-tuotantosuunnittain

Nevala-Puranen, N., Kallionpää, M. \& Ojanen, K. 1996. Physical load and strain in parlor milking. Intern J Industr Ergon 18: 277-282.

Pinzke, S. 2003. Changes in working conditions and health among dairy farmers in southern Sweden - a 14-year follow-up. Ann Agric Environ Med 10: 185-195.

Pinzke, S., Stål, M. \& Hansson, G-Å. 2001. Physical workload on upper extremities in various operations during machine milking. Ann Agric Environ Med 8: 63-70.

Stål, M., Pinzke, S. Hansson, G-A. \& Kolstrup, C. 2003. Highly repetitive work operations in a modern milking system - a case study of wrist positions and movements in a rotary system. Ann Agric Environ med 10: 67-72.

Suomen Gallup Elintarviketieto Oy. 2006. Maatilojen kehitysnäkymät 2012. Viljelijäkyselyn tulokset. Sisäinen raportti. 